\title{
Heparin-Induced Thrombocytopenia: A Review
}

\author{
Bruno Girolami, M.D., Ph.D., ${ }^{1}$ and Antonio Girolami, M.D. ${ }^{2}$
}

Immune heparin-induced thrombocytopenia (HIT) is a relevant adverse drug reaction consisting in a hypercoagulable state caused by an anticoagulant agent. The incidence is $\sim 6.5 \%$ in patients receiving unfractionated heparin after orthopedic surgery, and is equal to or lower than $1 \%$ in other settings. HIT occurrence is a function of heparin type, duration of heparin administration, patient population, and gender. The pathogenesis is due to an antibody response to the complex heparin/platelet factor 4 in most cases, with secondary activation of platelets and coagulation, and finally increased thrombin generation. Thrombocytopenia, venous or arterial thrombosis, heparin-induced skin necrosis, adrenal hemorrhage, and transient amnesia can characterize the clinical course of HIT. Platelet monitoring in patients receiving heparin is indicated to early detect HIT. A thrombotic event can be the first manifestation of HIT. Laboratory demonstration of heparin-dependent platelet activation confirms the clinical diagnosis; antigenic or functional assays are available. Once HIT is highly likely or confirmed serologically, immediate heparin cessation is mandatory and an alternative therapeutic anticoagulant is needed due to the high risk (or the presence) of thrombotic events. The available nonheparin anticoagulants aim to reduce thrombin generation. Lepirudin, argatroban, and bivalirudin (direct thrombin inhibitors) and danaparoid and fondaparinux (factor $\mathrm{Xa}$ inhibitors) represent the current treatment options for HIT. Vitamin K antagonists can be used safely only after a stable platelet count has been obtained.

KEYWORDS: Heparin-induced thrombocytopenia, heparin therapy, review

Of the two identified forms of heparin-induced thrombocytopenia (HIT; Table 1), the immune type (HIT type 2) represents a relevant adverse drug reaction. Although HIT type has a benign course, with platelet counts recovering without heparin withdrawal and no clinical consequences, HIT type constitutes a clinicalpathological syndrome with a strong association with thrombotic events. Immediate heparin withdrawal is required, and in most cases, an alternative anticoagulant must be administered. ${ }^{1,2}$

HIT type 2, the object of this review, can be defined as an unexplained thrombocytopenia of $50 \%$ or more compared with any previous value during exposure to unfractionated heparin (UFH) or low molecular weight heparin (LMWH), ${ }^{3}$ confirmed by the demonstration of specific antibodies against the heparin-platelet factor 4 (PF4) complex by means of a functional and/or antigenic assay. ${ }^{4,5}$ In this article, we will refer to HIT type 2 simply as HIT.

\section{EPIDEMIOLOGY}

The reported frequencies of HIT vary widely. In a review of prospective trials, the reported estimates ranged from

\footnotetext{
${ }^{1}$ Department of Medicine, Azienda Ospedaliera di Padova, Padova, Italy; ${ }^{2}$ University of Padua Medical School, Department of Medical and Surgical Sciences, Padua, Italy.

Address for correspondence: Bruno Girolami, M.D., Ph.D., Azienda Ospedaliera di Padova Via Giustiniani 235100 Padova, Italy. E-mail: bruno.girolami@sanita.padova.it.
}

Deep Vein Thrombosis and Pulmonary Embolism, Part 2; Guest Editor, Paolo Prandoni, M.D., Ph.D.

Semin Thromb Hemost 2006;32:803-809. Copyright (C) 2006 by Thieme Medical Publishers, Inc., 333 Seventh Avenue, New York, NY 10001, USA. Tel: +1(212) 584-4662.

DOI 10.1055/s-2006-955463. ISSN 0094-6176. 
Table 1 Main Features of the Two Different Forms of Heparin-Induced Thrombocytopenia (HIT)

\begin{tabular}{lll}
\hline Feature & Type 1 & Type 2 \\
\hline Frequency & Up to 20\% & Up to 5\% \\
Onset & $1-4 \mathrm{~d}$ & $5-14 \mathrm{~d}$ \\
Pathogenesis & Heparin-induced aggregation & Antibody to PF4-heparin complex \\
Thrombosis & No & Yes \\
Management & No heparin withdrawal required & Heparin withdrawal mandatory+alternative anticoagulation \\
\hline
\end{tabular}

PF4, platelet factor 4 .

1 to $30 \%$ among patients receiving $\mathrm{UFH}$ and $2 \%$ in patients receiving $\mathrm{LMWH} .{ }^{6}$ In a more rigorous review, the estimated incidence was lower than $3 \%$ with UFH, and $0 \%$ with LMWH. ${ }^{6 a}$ Considering only prospective studies in which an appropriate definition of HIT is present $(50 \%$ platelet count decrease or thrombotic event with a positive antibody assay or satisfactory clinical criteria for HIT), the frequency of HIT results as reported in Table 2, according to different patient populations and different heparin compounds. HIT is more frequent in patients who have had orthopedic surgery ${ }^{3,7-10}$ (up to $6.5 \%$ when receiving UFH), and is equal to or lower than $1 \%$ in other settings. ${ }^{11-18}$ Notably, LMWHs are not free of risk in terms of HIT compared

Table 2 Prospective Studies Evaluating the Incidence of Immune HIT in Different Patient Populations, Receiving UFH or LMWH

\begin{tabular}{|c|c|}
\hline Reference & Incidence (\%) \\
\hline \multicolumn{2}{|c|}{ After orthopedic surgery, UFH } \\
\hline Ganzer et $\mathrm{al}^{7}$ & 6.5 \\
\hline Mahlfeld et $\mathrm{al}^{8}$ & 2 \\
\hline Warkentin et $\mathrm{al}^{3}$ & 4.8 \\
\hline \multicolumn{2}{|c|}{ After orthopedic surgery, LMWH } \\
\hline Ganzer et $\mathrm{al}^{9}$ & 0 \\
\hline Marx et al ${ }^{10}$ & 0 \\
\hline Mahlfeld et $\mathrm{al}^{8}$ & 0.4 \\
\hline Warkentin et al ${ }^{11}$ & 0.6 \\
\hline \multicolumn{2}{|l|}{ After heart surgery, UFH } \\
\hline Warkentin et $\mathrm{al}^{4}$ & 1 \\
\hline \multicolumn{2}{|c|}{ After general or vascular surgery, UFH and LMWH } \\
\hline Calaitges et $\mathrm{al}^{12}$ & 0 \\
\hline Lindhoff-Last et al ${ }^{13}$ & 0 \\
\hline \multicolumn{2}{|l|}{ Medical patients, UFH } \\
\hline Kappers-Klunne et $\mathrm{al}^{14}$ & 0.3 \\
\hline Lozano et $\mathrm{al}^{15}$ & 0.9 \\
\hline Lindhoff-Last et al ${ }^{16}$ & 0.5 \\
\hline Girolami et al ${ }^{17}$ & 0.8 \\
\hline \multicolumn{2}{|l|}{ Medical patients, LMWH } \\
\hline Lindhoff-Last et al ${ }^{16}$ & 0.5 \\
\hline Prandoni et al ${ }^{18}$ & 0.8 \\
\hline
\end{tabular}

Study inclusion criteria: prospective (randomized studies, single- or double-cohort studies), declared adequate definition of HIT, laboratory demonstration of antibodies, or presence of stringent clinical criteria.

HIT, heparin-induced thrombocytopenia; UFH, unfractionated heparin; LMWH, low molecular weight heparin. with UFH. HIT occurrence is a function of heparin type (bovine UFH > porcine UFH > LMWH), duration of heparin administration (higher risk from days 5 to 14), gender (female $>$ male), ${ }^{2}$ HIT definition, and type of test used for detecting heparin-dependent antibodies. ${ }^{11}$ In general, antibodies are more likely to form in patients undergoing cardiac surgery than orthopedic surgery, as well as in orthopedic surgery patients who receive UFH instead of LMWH. However, among patients in whom antibodies do form, orthopedic patients are much more likely to develop HIT. ${ }^{11}$

\section{PATHOGENESIS}

Heparin administration can trigger an antibody response, given that antibodies are produced against the heparin-PF4 complex ${ }^{19-22}$ in some patients, ${ }^{11}$ depending on heparin molecular weight. ${ }^{23} \mathrm{PF} 4$ is the most important antigen, ${ }^{14}$ but the neutrophil-activating peptide 2 and interleukin 8 may also be involved. ${ }^{24}$ After heparin binds to PF4, a conformational change within PF4 determines the exposition of epitopes, ${ }^{25,26}$ and immunoglobulin M (IgM), IgA, or IgG antibodies are produced consequently. Clinically, only the $\mathrm{IgG}$ class antibodies are pathogenic ${ }^{27}$ and associated with thrombosis. The heparin-PF4-antibody complex binds to the platelet surface Fc $\gamma$ RIIa receptor. ${ }^{19,28}$ Cross-linking of FcyRIIa results in activation of platelets and the coagulation cascade with thrombin generation (a potent platelet activator). Because additional PF4 is released, a positive-feedback loop enhances the process. ${ }^{29}$ Activated platelets aggregate and are removed prematurely from the circulation, leading to thrombocytopenia and, in some patients, to venous or arterial thrombosis. In summary, HIT pathogenesis can be described as a three-step process: first, the antibodies are generated (immune response); second, platelets are activated and thrombin generation is increased (hypercoagulable state); third, in some unpredictable patients, thrombosis occurs (clinical-pathological syndrome).

\section{CLINICAL MANIFESTATIONS}

Thrombocytopenia typically occurs 5 to 10 days after initiation of heparin. ${ }^{1}$ However, in the particular case of an early re-exposure to heparin in patients who developed 
anti-PF4-heparin antibodies in the previous 100 days, onset may be earlier and rapid. ${ }^{30}$ In general, an onset of thrombocytopenia after 2 weeks is unusual. However, a delayed onset of HIT also has been described ${ }^{31}$ in which thrombocytopenia developed after heparin withdrawal. In general, thrombocytopenia rarely is severe, with median nadir platelet counts of $\sim 60 \times 10^{9} / \mathrm{L}^{32}$ and it is rarely associated with bleeding.

Thrombosis, venous and/or arterial, is the major clinical problem associated with HIT. The prothrombotic state associated with HIT is due to thrombin generation, platelet activation, and endothelial cell activation. ${ }^{33}$ The frequency of venous thrombosis in HIT patients reaches $90 \%$ in patients after orthopedic surgery, whereas arterial thrombosis occurs less frequently. Approximately one half of patients with HIT are recognized only after the occurrence of a complicating thrombotic event. The risk of thrombosis after HIT is higher than $50 \%$ in the first 30 days. ${ }^{34}$ Deep vein thrombosis and (fatal) pulmonary embolism are the most relevant thrombotic events in HIT patients. Other thrombotic manifestations include venous limb gangrene, cerebral sinus thrombosis, and upper extremity deep vein thrombosis. Arterial thrombosis can lead to stroke, myocardial infarction, limb ischemia from peripheral arterial occlusion, and bowel or kidney infarction. Heparin-induced skin necrosis may occur in fat-rich areas or in distal extremities and the nose; erythema is followed by purpura and hemorrhage, leading to necrosis. Other unusual complications of HIT include adrenal hemorrhage and transient global amnesia. 35,36

\section{DIAGNOSIS}

The diagnosis of HIT initially is clinical. An awareness of the syndrome is necessary to suggest HIT in cases of unexplained thrombocytopenia during heparin exposure, in the case of (new or worsening) thrombosis during heparin prophylaxis or treatment, or even in the case of thrombocytopenia or thrombosis after heparin withdrawal. Furthermore, the assays with the highest sensitivity and specificity are not available in many centers, and are time consuming and expensive. Clinical scores have been developed in the past to support the clinical diagnosis of HIT. ${ }^{4,5}$ These scoring systems are able to stratify patients as unlikely, likely, or highly likely to have HIT, on the basis of several parameters (platelet decrease, temporal aspects of platelet decrease, platelet recovery after heparin withdrawal, presence of cutaneous reactions, or thrombosis or other causes of thrombocytopenia). Recently, a pretest probability score has been developed $^{2}$ to suggest HIT and it is listed briefly in Table 3. Early diagnosis is also dependent on the frequency of platelet monitoring. It is recommended to perform platelet counts every other day in patients receiving therapeutic dose of UFH or in postoperative patients receiving UFH prophylaxis, whereas in medical patients receiving prophylactic UFH or LMWH, or postoperative patients receiving LMWH prophylaxis, platelet counts can be performed every 2 or 3 days. ${ }^{1,18}$

Once a high suspicion of HIT has been formulated, the diagnosis should be confirmed with the demonstration of heparin-dependent platelet activation. The most specific diagnostic tests for HIT include platelet aggregation tests, serotonin release assays, heparin-induced platelet aggregation assays, and solid-phase immunoassays (enzyme-linked immunosorbent assay [ELISA]). The main features of the available assays are listed in Table 4 . The serotonin release assay represents the gold standard of the diagnostic tests for $\mathrm{HIT}^{4}$ and has been validated with a prospective study ${ }^{37}$; however, it is costly and requires technical expertise. The

Table 3 Pretest Probability of HIT According to Thrombocytopenia, Timing of Platelet Decrease, Presence of Thrombosis, and Other Causes of Platelet Count Decrease

\begin{tabular}{|c|c|c|c|}
\hline \multirow[b]{2}{*}{ Parameter } & \multicolumn{3}{|c|}{ Points for Each of the Four Parameters } \\
\hline & 2 & 1 & 0 \\
\hline Thrombocytopenia & $>50 \%$ decrease or nadir $20-100 \times 10^{9} / \mathrm{L}$ & $\begin{array}{l}30-50 \% \text { decrease or } \\
\text { nadir } 10-19 \times 10^{9} / \mathrm{L}\end{array}$ & $\begin{array}{l}<30 \% \text { decrease or nadir } \\
\quad<10 \times 10^{9} / \mathrm{L}\end{array}$ \\
\hline $\begin{array}{l}\text { Timing of platelet } \\
\text { decrease }\end{array}$ & $\begin{array}{l}\text { Onset between days } 5 \text { and } 10 \text { (or } \\
\text { less than } 1 \mathrm{~d} \text { if heparin exposure } \\
\text { within previous } 100 \mathrm{~d} \text { ) }\end{array}$ & $\begin{array}{l}\text { Consistent with immunization } \\
\text { but not clear, or onset after day } 10\end{array}$ & $\begin{array}{l}\text { Platelet decrease too } \\
\text { early (without recent } \\
\text { heparin exposure) }\end{array}$ \\
\hline $\begin{array}{l}\text { Thrombosis or other } \\
\text { sequelae }\end{array}$ & $\begin{array}{l}\text { New thrombosis; skin necrosis; } \\
\text { post-heparin bolus acute } \\
\text { systemic reaction }\end{array}$ & $\begin{array}{l}\text { Progressive or recurrent thrombosis; } \\
\text { erythematous skin lesions; } \\
\text { suspicion of thrombosis }\end{array}$ & None \\
\hline $\begin{array}{l}\text { Other causes of } \\
\text { thrombocytopenia }\end{array}$ & No evidence & Possible & Definite \\
\hline
\end{tabular}

Pretest probability score: 6-8, high; 4-5, intermediate; 0-3, low.

HIT, heparin-induced thrombocytopenia.

(From Warkentin TE. Heparin-induced thrombocytopenia: pathogenesis and management. Br J Haematol 2003;121:535-555.) 
Table 4 Assays Available for the Laboratory Diagnosis of HIT

\begin{tabular}{|c|c|c|c|c|}
\hline Assay Type & Components & Measure & Advantages & Limits \\
\hline \multicolumn{5}{|l|}{ Functional assays } \\
\hline $\begin{array}{l}\text { Platelet aggregation } \\
\text { tests }\end{array}$ & $\begin{array}{l}\text { Test plasma, donor platelet-rich } \\
\text { plasma, heparin }\end{array}$ & Platelet aggregation & Easy, specific & $\begin{array}{l}\text { Variability, low } \\
\text { sensitivity }\end{array}$ \\
\hline $\begin{array}{l}{ }^{14} \mathrm{C} \text {-serotonin release } \\
\text { assay }\end{array}$ & $\begin{array}{l}\text { Test plasma, donor }{ }^{14} \mathrm{C} \text {-serotonin- } \\
\text { radiolabeled washed platelets, } \\
\text { heparin }\end{array}$ & $\begin{array}{l}{ }^{14} \text { C-serotonin release from } \\
\text { platelets }\end{array}$ & Sensitive & $\begin{array}{l}\text { Radionuclide, } \\
\text { expensive }\end{array}$ \\
\hline $\begin{array}{l}\text { Heparin-induced platelet } \\
\text { aggregation }\end{array}$ & $\begin{array}{l}\text { Test plasma, donor washed } \\
\text { platelets or platelet-rich } \\
\text { plasma, heparin }\end{array}$ & Platelet aggregation & Easy, sensitive & Variability \\
\hline \multicolumn{5}{|l|}{ Immunoassays } \\
\hline PF4/heparin ELISA & $\begin{array}{l}\text { Test plasma, PF4-heparin } \\
\text { complexes coated on } \\
\text { microtiter plates }\end{array}$ & $\begin{array}{l}\text { Presence of heparin- } \\
\text { dependent antibodies }\end{array}$ & $\begin{array}{l}\text { Easy, fast, } \\
\text { sensitive }\end{array}$ & $\begin{array}{l}\text { Detects only } \\
\text { antibodies against } \\
\text { the PF4-heparin } \\
\text { complex }\end{array}$ \\
\hline
\end{tabular}

HIT, heparin-induced thrombocytopenia; ELISA, enzyme-linked immunosorbent assay; PF4, platelet factor 4.

(From Fabris F, Luzzatto G, Stefani PM, Girolami B, Cella G. Heparin-induced thrombocytopenia. Haematologica 2000;85:72-81.)

ELISA assay, which has a lower sensitivity (it detects only IgG/IgM antibodies), should be used in conjunction with a functional assay. If the two tests are negative, HIT is ruled out.

\section{TREATMENT}

The increased thrombin generation present in HIT is the target of drug therapy. In fact, available agents aim to reduce thrombin generation directly (direct thrombin inhibitors) or by means of factor (F) Xa inhibition (danaparoid and fondaparinux). ${ }^{1}$ The evidence supporting the use of these drugs comes mainly from prospective cohort studies (lepirudin and argatroban) ${ }^{38-42}$ or retrospective studies (danaparoid). ${ }^{43-46}$ Table 5 summarizes the main features of these compounds. Isolated seroconversion without thrombocytopenia or thrombosis does not require any treatment or heparin withdrawal. In contrast, confirmed HIT without thrombosis (isolated HIT) requires heparin cessation and an alternative form of anticoagulation, given that the patients remain at risk for thrombosis in the short term, ${ }^{34}$ and heparin withdrawal alone does not protect these patients from thrombotic complications. LMWH should be avoided because of cross-reactivity and risk of induction of heparin-dependent IgG antibodies. Therapy with nonheparin anti-FXa or anti-FIIa inhibitors should be maintained until a stable normal platelet count has been obtained. Patients with HIT complicated with thrombosis require an alternative anticoagulant, as do patients with isolated HIT. Warfarin can be started safely after platelet counts are normalized. The length of treatment with warfarin is not well defined, but in view of the high risk of thrombosis within 30 days of the diagnosis of HIT, warfarin anticoagulation probably should be continued for at least 2 to 3 months. ${ }^{1}$ Table 6 lists the main issues in the management of patients with HIT, with or without thrombosis.

Lepirudin, recombinant hirudin, is approved in the United States for treatment of HIT with thrombosis and is effective in preventing new thromboses in HIT patients without thrombosis, according to prospective studies. ${ }^{47}$ In a prospective cohort of 82 patients with confirmed HIT, lepirudin led to a rapid platelet count recovery in $89 \%$ of patients and a significant decrease of a combined end point (death, amputation, and new thromboembolic events) compared with historical controls (25 versus $52 \%$ ), with no differences in terms of bleeding complications. ${ }^{48}$ Given that the drug is cleared by the kidneys and no antidote is available, the dosage of lepirudin needs to be decreased in nephropathic patients.

Argatroban, a synthetic direct thrombin inhibitor, is approved in the United States for the treatment of HIT regardless of the presence of thrombosis and during angioplasty when heparin is contraindicated. ${ }^{1,49}$ Because argatroban is metabolized mostly by the liver and excreted in the bile, a lower starting dosage is suggested in patients with hepatic dysfunction. A pooled analysis of two prospective cohort studies and a historical control group showed a significant $14 \%$ decrease in the primary outcome (all-cause death, all-cause amputation, new thrombosis) in patients with HIT with or without thrombosis and treated with argatroban. ${ }^{50}$ The positive result is due mainly to a decrease in new (venous) thrombosis. No differences in terms of bleeding were observed.

Bivalirudin, a recent and promising synthetic hirudin analogue, has been used in patients with HIT, but only uncontrolled case series are available. It is 
Table 5 Drugs for the Treatment of Patients with HIT, with or without Thrombosis

\begin{tabular}{|c|c|c|c|c|c|}
\hline Drug & Principle & $\begin{array}{l}\text { Plasma } \\
\text { Half-Life }\end{array}$ & Elimination & Monitoring & Adverse Reactions \\
\hline \multicolumn{6}{|c|}{ Direct thrombin inhibitors } \\
\hline Lepirudin & Recombinant hirudin & $1-2 \mathrm{~h}$ & Renal $(90 \%)$ & $\begin{array}{l}\text { aPTT, ecarin clotting } \\
\text { time }\end{array}$ & $\begin{array}{l}\text { Bleeding, antihirudin } \\
\text { antibodies, } \\
\text { anaphylactic } \\
\text { reactions }\end{array}$ \\
\hline Argatroban & Synthetic thrombin inhibitor & $0.8 \mathrm{~h}$ & Liver & aPTT & Bleeding \\
\hline Bivalirudin & Synthetic thrombin inhibitor & $0.5 \mathrm{~h}$ & $\begin{array}{c}\text { Enzymic }(80 \%), \\
\text { renal }(20 \%)\end{array}$ & $\begin{array}{l}\text { aPTT, ecarin clotting } \\
\text { time }\end{array}$ & Bleeding \\
\hline \multicolumn{6}{|c|}{ Factor Xa inhibitors } \\
\hline Danaparoid & Heparinoid & $24 \mathrm{~h}$ & Renal & Anti-F Xa activity & $\begin{array}{l}\text { In vitro cross-reaction } \\
\text { with HIT antibodies, } \\
\text { bleeding }\end{array}$ \\
\hline Fondaparinux & Synthetic pentasaccharide & $18 \mathrm{~h}$ & Renal & Anti-F Xa activity & Bleeding \\
\hline
\end{tabular}

HIT, heparin-induced thrombocytopenia; aPTT, activated partial thromboplastin time.

Table 6 Management Issues for Patients with Strongly Suspected or Serologically Confirmed HIT, with or without Thrombosis

Immediate heparin withdrawal

Alternative nonheparin anticoagulant at therapeutic doses

Routine ultrasonography of lower limbs

Avoid vitamin $\mathrm{K}$ antagonists (to avoid protein $\mathrm{C}$ decline with further hypercoagulable state)

Start (low dose) vitamin K antagonists only when a stable platelet count recovery has been obtained; overlap of at least $5 \mathrm{~d}$ with nonheparin anticoagulant

Avoid LMWH (cross-reactivity)

Avoid platelet transfusion in the absence of bleeding

HIT, heparin-induced thrombocytopenia; LMWH, low molecular weight heparin.

(From Warkentin TE, Greinacher A. Heparin-induced thrombocytopenia: recognition, treatment, and prevention: the Seventh ACCP Conference on Antithrombotic and Thrombolytic Therapy. Chest 2004;126:311S-337S.)

approved in the United States for anticoagulation during percutaneous coronary interventions. ${ }^{1}$

Danaparoid, a heparinoid (dermatan sulfate and low-sulfated heparan sulfate), is used in Europe, Canada, and New Zealand for HIT with or without thrombosis, ${ }^{45}$ and in patients with a history of HIT who require cardiopulmonary bypass surgery. ${ }^{51}$ In a nonrandomized comparison study, danaparoid was as effective as lepirudin in preventing death, amputation, or new thromboembolic complications with a lower risk of bleeding. ${ }^{52}$ Whether the $10 \%$ in vitro cross-reactivity between danaparoid and the antibody responsible for HIT is of clinical significance is uncertain. No reversing agent is available.

Fondaparinux has a theoretical role in the treatment and/or prevention of HIT, given that the drug does not appear to interact with platelets or PF4. Only case reports on its use in patients with HIT are available.

To prevent HIT, the following strategies can be suggested: limit heparin use, avoid bovine UFH, overlap warfarin as soon as possible to limit heparin exposure, and use LMWHs, particularly in the orthopedic setting. ${ }^{1}$ Patients with a history of HIT can be re-exposed safely to UFH if assays for antibodies are negative; this generally occurs 100 days after HIT.

\section{REFERENCES}

1. Warkentin TE, Greinacher A. Heparin-induced thrombocytopenia: recognition, treatment, and prevention: the Seventh ACCP Conference on Antithrombotic and Thrombolytic Therapy. Chest 2004;126:311S-337S

2. Warkentin TE. Heparin-induced thrombocytopenia: pathogenesis and management. Br J Haematol 2003;121:535-555

3. Warkentin TE, Roberts RS, Hirsh J, Kelton JG. An improved definition of immune heparin-induced thrombocytopenia in postoperative orthopedic patients. Arch Intern Med 2003;163:2518-2524

4. Sheridan D, Carter C, Kelton JG. A diagnostic test for heparin-induced thrombocytopenia. Blood 1986;67:27-30

5. Greinacher A, Amiral J, Dummel V, et al. Laboratory diagnosis of heparin-associated thrombocytopenia and comparison of platelet aggregation test, heparin-induced platelet activation test, and platelet factor 4/heparin enzyme-linked immunosorbent assay. Transfusion 1994; 34:381-385

6. Chong BH. Heparin induced thrombocytopenia. Aust NZ J Med 1992;22:145-152

6a. Schmitt BP, Adelman B. Heparin-associated thrombocytopenia: a critical review and pooled analysis. Am J Med 1993;305:221-225

7. Ganzer D, Gutezeit A, Mayer G, Greinecher A, Eichler P. Prevention of thromboembolism as a cause of thromboembolic complications. A study of the incidence of 
heparin-induced thrombocytopenia type II. Z Orthop Ihre Grenzgeb 1997;135:543-549

8. Mahlfeld K, Franke J, Schaeper O, Kayser R, Grasshoff H. Heparin-induced thrombocytopenia as a complication of postoperative prevention of thromboembolism with unfractionated heparin/low molecular weight heparin after hip and knee prosthesis implantation. Unfallchirurg 2002;105:327331

9. Ganzer D, Gutezeit A, Mayer G. Potentials risks in drug prevention of thrombosis-low-molecular-weight heparin versus standard heparin. Z Orthop Ihre Grenzgeb 1999; 137:457-461

10. Marx A, Huhle G, Hoffmann U, et al. Heparin-induced thrombocytopenia after elective hip joint replacement with postoperative prevention of thromboembolism with lowmolecular-weight heparin. Z Orthop Ihre Grenzgeb 1999; 137:536-539

11. Warkentin TE, Sheppard JA, Horsewood P, et al. Impact of the patient population on the risk for heparin-induced thrombocytopenia. Blood 2000;96:1703-1708

12. Calaitges JG, Liem TK, Spadone D, Nichols WK, Silver D. The role of heparin-associated antiplatelet antibodies in the outcome of arterial reconstruction. J Vasc Surg 1999;29:779785

13. Lindhoff-Last E, Eichler P, Stein M, et al. A prospective study on the incidence and clinical relevance of heparininduced antibodies in patients after vascular surgery. Thromb Res 2000;97:387-393

14. Kappers-Klunne MC, Boon DM, Hop WC, et al. Heparininduced thrombocytopenia and thrombosis: a prospective analysis of the incidence in patients with heart and cerebrovascular diseases. Br J Haematol 1997;96:442-446

15. Lozano M, Perez S, Cid J, et al. Is the incidence of heparin induced thrombocytopenia the same everywhere? The case of Spain. Thromb Haemost 2001(suppl); XVIII Congress ISTH (abst P2718)

16. Lindhoff-Last E, Nakov R, Misselwitz F, Breddin HK, Bauersachs R. Incidence and clinical relevance of heparininduced antibodies in patients with deep vein thrombosis treated with unfractionated or low-molecular-weight heparin. Br J Haematol 2002;118:1137-1142

17. Girolami B, Prandoni P, Stefani PM, et al. The incidence of heparin-induced thrombocytopenia in hospitalized medical patients treated with subcutaneous unfractionated heparin: a prospective cohort study. Blood 2003;101:29552959

18. Prandoni P, Siragusa S, Girolami B, Fabris F; BELZONI Investigators Group. The incidence of heparin-induced thrombocytopenia in medical patients treated with lowmolecular-weight heparin: a prospective cohort study. Blood 2005;106:3049-3054

19. Visentin GP, Ford SE, Scott JP, Aster LH. Antibodies from patients with heparin-induced thrombocytopenia/thrombosis are specific for platelet factor 4 complexed with heparin or bound to endothelial cells. J Clin Invest 1994;93:81-88

20. Amiral J, Bridey F, Dreyfus M, et al. Platelet factor 4 complexed to heparin is the target for antibodies generated in heparin-induced thrombocytopenia. Thromb Haemost 1992; 68:95-96

21. Kelton JG, Smith JW, Warkentin TE, et al. Immunoglobulin $\mathrm{G}$ from patients with heparin-induced thrombocytopenia binds to a complex of heparin and platelet factor 4. Blood 1994;83:3232-3239
22. Rauova L, Poncz M, McKenzie SE, et al. Ultralarge complexes of PF4 and heparin are central to the pathogenesis of heparin-induced thrombocytopenia. Blood 2005;105:131138

23. Greinacher A, Alban S, Kummel V, et al. Characterization of the structural requirements for a carbohydrate based anticoagulant with a reduced risk of inducing the immunological type of heparin-associated thrombocytopenia. Thromb Haemost 1995;74:886-892

24. Amiral J, Meyer D. Heparin-dependent antigens in heparininduced antibodies. In: Warketin TE, Greinecher A, eds. Heparin-Induced Thrombocytopenia. 3rd ed. New York, NY: Marcel Dekker; 2004:165-178

25. Ziporen L, Li ZQ, Park KS, et al. Defining an antigenic epitope on platelet factor 4 associated with heparin-induced thrombocytopenia. Blood 1998;92:3250-3259

26. Li ZQ Liu W, Park KS, et al. Defining a second epitome for heparin-induced thrombocytopenia/thrombosis antibodies using $\mathrm{KKO}$, a murine HIT-like monoclonal antibody. Blood 2002;99:1230-1236

27. Suh JS, Malik MI, Aster RH, et al. Characterization of the humoral immune response in heparin-induced thrombocytopenia. Am J Hematol 1997;54:196-201

28. Greinacher A, Potzsch B, Amiral J, et al. Heparin-associated thrombocytopenia: isolation of the antibody and characterization of a multimolecular PF4-heparin complex as the major antigen. Thromb Haemost 1994;71:247-251

29. Newman PM, Chong BH. Heparin-induced thrombocytopenia: new evidence for the dynamic binding of purified antiPF4-heparin antibodies to platelets and the resultant platelet activation. Blood 2000;96:182-187

30. Warkentin TE, Kelton JG. Temporal aspects of heparininduced thrombocytopenia. N Engl J Med 2001;344:12861292

31. Warkentin TE, Kelton JG. Delayed-onset heparin-induced thrombocytopenia and thrombosis. Ann Intern Med 2001; 135:502-506

32. Warkentin TE. Clinical presentation of heparin-induced thrombocytopenia. Semin Hematol 1998;35:9-16

33. Blank M, Shoenfeld Y, Tavor S, et al. Anti-platelet factor 4/ heparin antibodies from patients with heparin-induced thrombocytopenia provoke direct activation of microvascular endothelial cells. Int Immunol 2002;14:121-129

34. Warkentin TE, Kelton JG. A 14-year study of heparininduced thrombocytopenia. Am J Med 1996;101:502-507

35. Arthur CK, Grant SJB, Murray WK, et al. Heparinassociated acute adrenal insufficiency. Aust NZ J Med 1985; 15:454-455

36. Warkentin TE, Hirte HW, Anderson DR, et al. Transient global amnesia associated with acute heparin-induced thrombocytopenia. Am J Med 1994;97:489-491

37. Warkentin TE, Levine MN, Hirsh J, et al. Heparin-induced thrombocytopenia in patients treated with low-molecularweight heparin or unfractionated heparin. N Engl J Med 1995;332:1330-1335

38. Greinacher A, Völpel H, Janssens Uet al, for the HIT Investigators Group. Recombinant hirudin (lepirudin) provides safe and effective anticoagulation in patients with heparin-induced thrombocytopenia: a prospective study. Circulation 1999;99:73-80

39. Greinacher A, Janssens U, Berg Get al, for the Heparin associated Thrombocytopenia Study (HAT) Investigators. Lepirudin (recombinant hirudin) for parenteral anticoagulation 
in patients with heparin-induced thrombocytopenia. Circulation 1999;100:587-593

40. Eichler P, Lubenow N, Greinacher A. Results of the third prospective study of treatment with lepirudin in patients with heparin-induced thrombocytopenia (HAT). Blood 2002; 100(suppl 1):704a (abst)

41. Lewis BE, Wallis DE, Berkowitz SD, et al. Argatroban anticoagulant therapy in patients with heparin-induced thrombocytopenia. Circulation 2001;103:1838-1843

42. Lewis BE, Wallis DE, Leya F, et al. Argatroban anticoagulation in patients with heparin-induced thrombocytopenia. Arch Intern Med 2003;163:1849-1856

43. Eichler P, Kroll H, Greinacher A. A comparison of danaparoid and lepirudin in heparin-induced thrombocytopenia. Thromb Haemost 2001;85:950-957

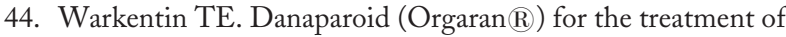
heparin-induced thrombocytopenia (HIT) and thrombosis: effects on in vivo thrombin and cross-linked fibrin generation, and evaluation of the clinical significance of in vitro cross-reactivity (XR) of danaparoid for HIT-IgG. Blood 1996;88(suppl 1):626a (abst)

45. Magnani HN. Heparin-induced thrombocytopenia (HIT): an overview of 230 patients treated with Orgaran (Org 10172). Thromb Haemost 1993;70:554-561
46. Magnani HN. Orgaran (danaparoid sodium) use in the syndrome of heparin-induced thrombocytopenia. Platelets 1997;8:74-81

47. Lubenow N, Eichler P, Lietz T, Farner B, Greinacher A. Lepirudin for prophylaxis of thrombosis in patients with acute isolated heparin-induced thrombocytopenia: an analysis of 3 prospective studies. Blood 2004;104:3072-3077

48. Greinacher A, Volpel H, Janssens V, et al. Recombinant hirudin (lepirudin) provides safe and effective anticoagulation in patients with heparin-induced thrombocytopenia: A prospective study. Circulation 1999;99:73-80

49. Lewis BE, Wallis DE, Leya F, et al. Argatroban anticoagulation in patients with heparin-induced thrombocytopenia. Arch Intern Med 2003;163:1849-1856

50. Lewis BE. Argatroban in heparin-induced thrombocytopenia type II: clinical experience-trials and practice. Paper presented at: Symposium XIX ISTH Congress; July 12-18, 2003; Birmingham, UK

51. Gillis S, Merin G, Zahger D, et al. Danaparoid for cardiopulmonary bypass in patients with previous heparininduced thrombocytopenia. Br J Haematol 1997;98:657-659

52. Farner B, Eichler P, Kroll H, Greinacher A. A comparison of danaparoid and lepirudin in heparin-induced thrombocytopenia. Thromb Haemost 2001;85:950-957 